\title{
Factors of biologization of farming in the forest-steppe zone of Volga region
}

\author{
Aleksandr Toigildin*, Vladimir Morozov, Mikhail Podsevalov, Denis Ayupov, Irina Toigildina, and Rezida Mustafina
}

Ulyanovsk State Agrarian University named after P.A. Stolypin, 432017 Ulyanovsk, Russia

\begin{abstract}
The modern development of world farming was announced at the UN Conference on Environment and Development, and is connected with the biosphere paradigm of nature management (1992), which implies the priority of maintaining the ecological functions of soils and landscapes (ecologization). In agriculture, ecologization is known as "organic farming" (ecological, biological, etc.), but in Russia, "organic farming", in its pure form (without pesticides and chemical fertilizers), has not gained momentum yet. The legislative base for this was developed only in 2019 and in the coming years it is unlikely to receive widespread distribution among representatives of agribusiness for economic, social and cultural reasons. Further development of modern agribusiness is possible due to technological modernization through the technological upgrading by means of a system of biologization. In this article, we have revealed the main factors and practical methods of biologization of modern farming under the conditions of the forest-steppe zone of the Volga region.
\end{abstract}

\section{Introduction}

World farming and agricultural technologies of the last decades have undergone several revolutionary stages: cultivation of highly intensive varieties, the mastering of intensive technologies, genetic engineering, information technology. Technology-related intensification of farming, based on the widespread use of chemicals (fertilizers and pesticides), made it possible to increase the yield of crops and somewhat stabilize soil fertility, however, the return on resources invested in agricultural technologies, energy and economic efficiency of production started decreasing significantly [1]. High intensification led to environmental problems, which aroused public protest and heated debates, in which two standpoints were opposed: the first - a complete rejection of chemicalization; the second one is further intensification by creating high-tech precision technologies with minimal environmental risks [2]. The first standpoint was popular during the period of total chemicalization and, as a result, some ideas were put forward for the development of alternative farming systems that denied the use of mineral fertilizers and pesticides, among which biodynamic farming, ecological farming, organic farming and other forms that differ little from each other.

Later (in the 80s), there was an active search for the so-called third path - technological solutions integrating the economic, social and environmental aspects of farming. A fundamentally new approach to the methodology of agricultural development has emerged, defined by the term "sustainable agriculture", derived from the more general concept of "sustainable development", which reflects the concept of the future development of mankind, adopted in 1992 in Rio de Janeiro at the UN Conference on the Environment and Development.

In Russia, organic farming is not widespread due to the lack of a complete regulatory and legal framework and consumers. It should also be mentioned that organic farming in Russia with its various soil and climatic conditions, in its pure form, is not able to ensure the production of foodstuffs in the volume of public consumption and solve the issue of food security.

Meanwhile, the chemical intensification of agriculture has led to pollution of the resulting products and the environment, physical and biological degradation of soil fertility, a decrease in the biodiversity of agrophytocenoses, and other consequences. This makes it necessary to carry out technological modernization of existing farming on the basis of ecologization. According to a number of authors [3, 4], a promising expression of ecologization is biologization of farming, when the negative effect of chemical intensification factors is neutralized by biological factors.

\section{Results and discussion}

Terminology differences have been formed in many countries in defining the concept of alternative farming systems, which often lead to misunderstandings. According to a review of information conducted by Ya.A. Fedorenko [5] the term "organic farming" (Organic Farming (first used by Lord Walter Northbourne in 1940) is officially adopted in the

*Corresponding author: atoigildin@yandex.ru 
English-speaking countries of the European Union (EU), the equivalent term in France, Italy, Portugal and Benelux is "Biological farming" (Biological Farming), but in Denmark, Germany and Spain - «ecological farming» (Ekolological Farming).

The arrays of definitions have been attempted to describe organic farming. One of the first comprehensive definitions of the term "organic farming" belongs to a group of scientists from the US Department of Agriculture (Concept\&DefinitionUSDA, 1980): "Organic farming as a production system, which avoids or largely exclude the use of synthetically compounded fertilizers, pesticides, growth regulators, and livestock feed additives.

To the maximum extent possible organic farming system relies on crop rotation, crop residues, animal manures, legumes, green manures, farm organic wastes, mechanical cultivation mineral bearing rocks and aspects of biological pest control to maintain soil productivity and tilth, to supply plant nutrients, and to control insects, and other pests.

Such a system is maximally based on crop rotation, the use of plant residues, manure and composts, leguminous plants and plant fertilizers, organic waste products, mineral raw materials, soil tillage and biological pest control in order to increase soil fertility and improve soil structure, to ensure proper nutrition of plants and weed and pest control [6].

«Organic agriculture was defined by National Organic standards Board of the USA (1996) Organic farming - ecological production management system that promote and enhance biodiversity, biological activity. It is based on minimal use of off- farm inputs and on management practices that restore».

Codex Alimentarius Commission (FAO/WHO) defines "Organic farming as holistic food production management system, which promotes and enhances agro-ecosystem health, including biodiversity, biological cycles and soil biological activity.

The following definitions are also found in the literature: Organic agriculture is a system that aims to primarily use ecologic processes rather than external inputs to manage crops and livestock [7]. Organic agriculture $(\mathrm{OA})$ is a management system that avoids the use of synthetic pesticides, inorganic fertilizers, and genetically modified organisms (GMOs) and that seeks to reduce pollution (air, soil, and water) and optimize the health and productivity of interdependent communities of plants, animals, and humans [8].

On a global scale, organic farming, based on the complete rejection of technology-related resources, has occupied a certain niche, but has not received a wide distribution due to increased cost, low availability of plants in nutrients, problems with plant protection and low crop yields $[9,10]$.

Such a term and direction as "biologization" has become common in scientific agronomy, but its definition is interpreted differently, and therefore, methodological approaches to the development in different countries and scientific schools are not the same. According to the expression of V.I. Kiryushin
[11], biologization is the main expression of ecologization of agriculture.

In one of the latest editions of the Russian Academy of Sciences, prepared by the team of authors, the definition is given as "ecological direction (ecological course) - the process of the consistent implementation of the ideas of conservation of nature and environmental sustainability in the field of legislation, management, technology development, economics, education, etc." [12].

Undoubtedly, the farming of most Russian regions requires new approaches; more research is needed to study the possible ways of its technological modernization. Today, the necessary prerequisites have been created for solving this problem in the form of a methodology for the formation and design of adaptive landscape farming systems and high-tech agricultural technologies, in which adaptive intensification and ecologization of agriculture have been integrated.

V.I. Kiryushin [2,13] in his works emphasizes that the essence of ecologization of agriculture consists in bringing it in line with environmental laws, solving the problems of preserving biodiversity, adapting to agroecological conditions, optimizing the ratio of natural and agricultural land, harmonizing agriculture and animal husbandry, and creating the optimal infrastructure of agrolandscapes.

Some authors think that the essence of biologization is to minimize the difference in the decomposition of organic matter in the soil and its intake from various sources [14]. However, this approach is only part of a complex process of biologization.

The biologization (direction) and biological farming (the method of land use) are aimed at the decrease of the consequences of the use of intensification factors and is based on the rational use of biogenic intensification and biological factors of the plant production potential. In a simple approximation, the essence of biologization of farming can be expressed as an enhanced role of living organisms and plant biopotential in the production process and reproduction of soil fertility $[15,16]$.

Thus, organic farming, based on the complete rejection of chemical intensification means, is the highest manifestation of ecologization of agriculture. At the present stage of development, due to low productivity and high cost, it is not able to ensure food security of the country. Understanding the fact that deep chemical intensification is fraught with global environmental consequences makes us develop and actively orient existing farming to the processes of biologization (biological farming).

We have been doing research in the field of biologization of agriculture in the forest-steppe zone of the Volga region for more than 30 years, which allowed substantiating the factors and techniques of farming systems' biologization in this region (table 1).

The following biologization factors of farming have been identified: crop rotation, biological nitrogen, the system of organomineral fertilization, biological plant protection, soil-protective systems of soil tillage.

1) The most important biologization factor is crop rotation, which determines the diversity of species 
and varieties of cultivated plants (biodiversity). Biological diversity in agrophytocenoses is regulated by a set of main and intermediate crops in crop rotation. Crop rotation allows building a plant protection system, directly by changing the living conditions of harmful organisms and feed base for them, and indirectly, by creating conditions for the development of entomophages. With a wide variety of crops, the number of insectivorous predators is increasing that fight pests and help prevent plant diseases. All this leads to a decrease in the use of pesticides [7, 17-19].

It should be pointed out that one can expand the species composition and optimize the set of crops in crop rotation, in economic and environmental aspects, as well as ensure the systemic effect of crop rotation only with the development of animal husbandry. At the same time, it becomes possible to introduce perennial herbs, which, in addition to feed value, are extremely important for increasing soil fertility, protecting them from erosion, and optimizing the phytosanitary state of agrocenoses. A combination of farming and animal husbandry largely solves the problem of fertilizing crops and increasing the biological activity of the soil [2].

According to our studies, in view of conditions of the forest-steppe zone of the Volga region, crop rotation with perennial grasses are the most promising which allow obtaining feed resources and ensure reproduction of soil fertility. In the structure of sown areas of farms in the region, it is necessary to increase the share of sown fallow and fallow land with green manure (at least $60 \%$ of the sown area with winter grain crops), increase the area of perennial leguminous grasses and leguminouscereal mixtures to $25 \%$ of the arable land, as well as mixed crops and intermediate crops .

Table 1. Biologization factors of farming, scientific prerequisites and techniques for the conditions of the forest-steppe zone of the Volga region

\begin{tabular}{|c|l|l|l|}
\hline № & $\begin{array}{l}\text { Farming biologization } \\
\text { factors }\end{array}$ & Objective scientific prerequisites & \multicolumn{1}{|c|}{ Available techniques } \\
\hline 1 & Crop rotation & $\begin{array}{l}\text { Diversity of species and varieties of } \\
\text { cultivated plants (biodiversity). The } \\
\text { law of crop rotation. The concept of } \\
\text { the unity of crop production and } \\
\text { animal husbandry. Multi-species or } \\
\text { mixed crops. }\end{array}$ & $\begin{array}{l}\text { Farming based on crop rotation, intermediate crops } \\
\text { (rapeseed, mustard, oil radish, etc.). Mixed crops of } \\
\text { legumes and cereals (vetch + oats; peas + oats + barley, } \\
\text { etc.), mixtures of fodder crops (corn + soya; sunflower + } \\
\text { soya, etc. }\end{array}$ \\
\hline 2 & Biological nitrogen & $\begin{array}{l}\text { Symbiotic nitrogen fixation of } \\
\text { legumes }\end{array}$ & $\begin{array}{l}\text { Productivity of symbiotic nitrogen fixation cereal legumes } \\
\text { 30-100 kg/ha; perennial legumes up to 200-350 kg/ha. }\end{array}$ \\
\hline 3 & $\begin{array}{l}\text { Enrichment of the soil } \\
\text { with organic } \\
\text { matter.(organic and and } \\
\text { mineral systems of } \\
\text { fertilization) }\end{array}$ & $\begin{array}{l}\text { The law of returning. Theory of } \\
\text { reproduction of soil fertility. } \\
\text { Accumulation of biogenic resources } \\
\text { created in agrophytocenoses. }\end{array}$ & $\begin{array}{l}\text { Straw of grain crops and legumes, plant residues, green } \\
\text { manure, manure in the volume of 8 t/ha of dry matter. } \\
\text { Manure + calculated doses of NPK, straw + NPK, green } \\
\text { manure + NPK and their combination. Application rates } \\
\text { are adjusted in view of «the coeffcient of biologization of } \\
\text { farming». }\end{array}$ \\
\hline 4 & $\begin{array}{l}\text { Biological plant } \\
\text { protection }\end{array}$ & $\begin{array}{l}\text { The use of biological means of } \\
\text { plant protection, entomophages, } \\
\text { increasing the competitiveness of } \\
\text { field crops in relation to the weed } \\
\text { component in agrophytocenoses. }\end{array}$ & $\begin{array}{l}\text { The use of bacterial, viral, fungal and other biological } \\
\text { products for the destruction of mass pests and pathogens. } \\
\text { Crop rotation with a set of crops capable of supporting a } \\
\text { high number of entomophages (buckwheat, canola, } \\
\text { phacelia, alfalfa, sainfoin, clover, etc.). Mixed and } \\
\text { intermediate crops. }\end{array}$ \\
\hline 5 & $\begin{array}{l}\text { Soil protective systems } \\
\text { of tillage }\end{array}$ & $\begin{array}{l}\text { Soird-forming process. Mulching. } \\
\text { no-till system }\end{array}$ \\
\hline
\end{tabular}

2) Biological nitrogen. It is well known that nitrogen of mineral fertilizers is characterized by high energy intensity, leads to an increase in the cost of crop production, as well as to an increase in the concentration of nitrates and nitrites, pollution of the soil, water sources and crop produce.

The alternative source of nitrogen is the ability of certain groups of microorganisms to bind it from the air; the process itself has a global function - maintaining the nitrogen status of the biosphere [20].

Romanov G.G. [21] points out that the attractiveness of "biological" nitrogen for agriculture as a source of nitrogen compounds lies in the fact that the reserves of molecular nitrogen in the atmosphere are practically inexhaustible, the enzymatic process of nitrogen fixation itself is carried out at ordinary temperatures and pressure, and the source of energy is sunlight which is free of charge. The maximum use of the process is environmentally and energetically acceptable and fully fits into the biosphere paradigm of environmental management, declared by the UN Conference on Environment and Development.

Biological nitrogen is one of the energy-efficient and environmentally friendly sources in crop production, and it is obvious that the species composition and the proportion of legumes in the structure of sown areas need to be expanded.

Therefore, the level of biologization of crop rotation is determined, in particular, by the productivity of symbiotic nitrogen fixation from the atmosphere by legume crops.

Among other things, legumes are a source of vegetable protein and essential amino acids, as well as one of the best predecessors in crop rotation. All this determines the importance of expanding the species composition of legumes in crop rotation and the 
development of techniques to increase their productivity and enhance symbiotic nitrogen fixation.

We recommend to reduce the share of complete fallow, but in sown fallow place leguminous crops peas, vetch, lupine, lupine with peas in two-component agrophytocenoses as sources of biological nitrogen and accumulation of vegetable protein. According to our data, in the Volga forest-steppe, legumes are characterized by high productivity of symbiotic nitrogen fixation: peas - up to $70 \mathrm{~kg} / \mathrm{ha}$, lupine - up to $99 \mathrm{~kg} / \mathrm{ha}$, vetch - up to $34 \mathrm{~kg} / \mathrm{ha}$.

The crops of alfalfa (up to $352 \mathrm{~kg} / \mathrm{ha}$ ), esparcet (up to $207 \mathrm{~kg} / \mathrm{ha}$ ) and a mixture of alfalfa + brome grass (up to $130 \mathrm{~kg} / \mathrm{ha}$ ) are distinguished by the highest productivity of symbiotic nitrogen fixation, which is explained in our works [22].

3) Enrichment of the soil with organic matter. One can come across the term soil health in the scientific literature. This is a functional biological category that reflects the state of the activity of the biotic component in the organomineral complex of the soil [12]. The organic matter of the soil, as a key indicator of fertility, forms and maintains the basic regimes, properties and functions of the soil, gives it the emergent properties of the system $[23,24]$.

The authors' teams have developed concepts for reproducing soil fertility and regulating the regime of soil organic matter in various regions of our country [25-27]. The main essence of the concepts is to use the biogenic resources created in agrophytocenoses as a source of soil organic matter. In case of biologization of farming, as a source of organic matter, along with application of manure, it is necessary to use straw of grain and leguminous crops (up to 1.5 million tons in the Ulyanovsk region) and other biogenic resources (crop and root crop residues, green manure, intermediate crops), which will enhance microbiological activity, improve the regime of organic matter and the waterphysical properties of the soil, and increase the productivity of crop rotation. The amount of biogenic resources entering the soil should be at least $8 \mathrm{t} / \mathrm{ha}$ of dry matter, which will ensure the optimization of the organic matter regime of black soils.

It is important to emphasize that half of the amount of plant mass named should remain on the surface of the soil in the form of mulch to reduce run-off, protect against soil washing, erosion. In general, a similar entry of labile organic matter into the soil helps to maintain its favorable structural state.

The solution to food security problems is possible by increasing the yield of crops on the land used, which leads to the widespread use of mineral fertilizers. It is obvious that a complete rejection of the use of mineral fertilizers in the organic farming system will lead to a decrease in yields. Meanwhile, the works of A. Lykov with co-authors [28]; Sycheva V.G. et al. [29] proved that their negative impact is neutralized by the use of organic fertilizers. Shikula, N., Dolja, N. in their works [30] noted that the concept of biologization is realized through the neutralization of the negative effect of mineral fertilizers, which is expressed in enhancing soil dehumification and degradation of agrophysical properties. According to the concept of biologization, not more than $15 \mathrm{~kg}$ of the active substance of mineral fertilizers should be introduced per 1 ton of organic fertilizers.

In field crop rotation, it is recommended to use organic-mineral fertilization systems: straw + NPK and green manure + straw + NPK. Doses of mineral fertilizers should be calculated in view of the planned yielding capacity of winter wheat 3.5-4.5 t/ha, spring wheat -3.0 $3.5 \mathrm{t} / \mathrm{ha}$, legumes $-2.5-3.0 \mathrm{t} / \mathrm{ha}$ of grain and productivity perennial grasses $-4.0-5.0$ thousand feed units.

4) Biological plant protection. Biologization of plant protection is possible due to techniques directed to preserving natural entomophages and antagonists [31]; the introduction of phytophages against certain species of weeds [32] and the use of biological products for the destruction of pests and pathogens.

In order to increase the efficiency of plant protection due to entomophages, it is necessary to have plants capable of maintaining their high numbers (buckwheat, rape, phacelia, alfalfa, esparcet, clover, etc.) among the cultivated crops; to plant nectariferous perennial plants (bird cherry, linden, maple, mountain ash, hawthorn, etc.) in shelterbelt forests; to leave strips when mowing perennial grasses; to use food attractants to attract entomophages; to carry out selective pesticidal treatment taking account of the ratio of the number of phytophages and entomophages [2].

With the biologization of farming, the role of chemical pesticides should decrease, and the share of environmentally friendly products based on Bacillus thuringiensis, Bacillus subtillus and others in their range should be increased. Several plants that produce biological products are effectively operating in the Volga region (in the cities of Penza, Kazan, Ulyanovsk) and this method is gaining popularity among agricultural producers.

5) Soil protection tillage systems. The shift to soilprotective tillage systems is due to the massive spread of degradation of soil fertility as a result of prolonged irrational use of agricultural land. Biologization of farming is directed towards the reduction or elimination of the soil cover destruction under the influence of abiotic and biotic factors (wind, water, chemicals and other factors). First of all, soil tillage should be differentiated depending on soil properties, biological requirements of crops, landscape-ecological and economic conditions [13]. The comparison of the optimal soil density for a particular crop with the equilibrium one should serve as the criterion to minimize soil cultivation. Judging by this criterion, we can assume that minimal tillage and direct sowing of grain and leguminous crops are possible for most of the soils of the Volga forest-steppe.

Direct sowing and no-till systems meet the requirements of soil conservation and reproduction of its fertility to a great extent [33-35]. The major factors that determine the prospects for the development of direct sowing and no-till are associated with the lack of mechanical tillage and the creation of a mulching layer from plant residues, which reduces the evaporation of moisture from the soil, suppresses weeds, protects the soil from erosion processes. At the same time it 
increases the biological activity of soils, the intensity of the processes of mineralization of organic matter decreases, the emission of $\mathrm{CO}^{2}$ decreases.

Despite the significant spread of this system in world farming, there are many doubts, skepticism about the introduction of direct sowing in Russia, attention is focused on its shortcomings, but the scientific community should continue developing recommendations on how to overcome these shortcomings for the sake of advantages that can be implemented in the best practices.

Thus, in order to master soil protection tillage systems, the agricultural community should comprehend the need to preserve the environment and reproduction of soil fertility, to solve the problems of training specialists and issues of the technical equipment of the system.

Crop rotation remains one of the main factors in the development of the direct sowing system. When selecting crops, it is important to take into account the ability of the root system to exert a loosening effect on the soil, thereby replacing the effect of deep tillage. Crops with a rod root system have the property of loosening the soil and are suitable for cultivation under the conditions of the forest-steppe zone of the Volga region. The following schemes can serve as an example of field crop rotation suitable for the development of a no-till system under the conditions of the forest-steppe zone of the Volga region: oil bearing crops (flax, rape, mustard) - winter wheat - legumes (peas, soybeans, lupins, chickpeas) - spring wheat - alfalfa ( emergency field) - spring grain crops.

The experience of the Belgorod region is an example of the wide and effective use of biologization in farming practice where green manure is used in combination with manure and straw every year in sown fallow and in intermediate crops over an area of more than 300 thousand ha. In the structure of cultivated areas, the proportion of legumes increased, and the sizes of symbiotic fixation of nitrogen reached $17.4 \mathrm{~kg} / \mathrm{ha}$ per year on average.

The combination of organic fertilizers with mineral ones and liming made it possible to surpass the level of soil fertility in the region of the late 80 s of the last century and ensure the stability of the crop and livestock sectors of the agro-industrial complex, according to the development of which the Belgorod region takes one of the first places in Russia [3].

\section{Conclusion}

On the fields of the forest-steppe zone of the Volga region, agricultural technologies are applied that are distinguished by a high degree of technology-related intensification, the use of high doses of mineral fertilizers and pesticides, which can lead to environmental problems. This forces to master ecologically acceptable agricultural technologies based on the principles of greening and biologization. The essence of biologization of agriculture is the development of factors and techniques in specific regional conditions:
- crop rotation supporting biological diversity due to different varieties, main and intermediate crops;

- biological nitrogen, due to the symbiosis of nitrogen-fixing bacteria and legumes, which will reduce the volume of nitrogen fertilizers and increase the economic and energy efficiency of agricultural technologies;

- enrichment of the soil with organic matter, development of organic-mineral fertilizer systems based on manure, straw and green manure, in view of the conditions of the forest-steppe zone of the Volga region at least $8 \mathrm{t} / \mathrm{ha}$ of dry matter;

- biological protection of plants by creating favorable conditions for the propagation of entomophages, the introduction of phytophages against individual species of weeds and the use of biological prrparations;

- soil protective tillage systems directed to protecting soils from erosion, reducing the volume of mineralization of soil organic matter, maintaining moisture, increasing the biological activity of the soil and reproducing other indicators of soil fertility.

The effectiveness of biologization in farming increases in the synergistic interaction of factors and techniques [36].

The system of biologization of farming in the foreststeppe zone of the Volga region will reduce the negative effect of technology-related intensification, will contribute to the reproduction of soil fertility and increase the economic and energy efficiency of agricultural production.

\section{Acknowledgments}

This work has been implemented with the support of grant MD-2909.2019.11.

\section{References}

1. A.A. Zhuchenko, Biologization, ecologization, energy saving, the economy of modern sustems of farming, Bull. of the Stavropol AIC, 52, 9-13 (2015)

2. V.I. Kiryushin, The problem of farming ecologization in Russia (the Belgorod model), Achiev. of sci. and engineer. in the AIC, 12, 3-9 (2012)

3. S.V. Lukin, The experience of biologization of farming in the Belgorod region, Agrochem. Bull., 5, 21-25 (2017)

4. V.G. Loshakov, Green manure as a factor of raising soil fertility, biologization and greening of farming, Fertility, 2(101), 26-29 (2018)

5. Ya. A. Fedorenko, The formative years and development of organic farming in the Ukraine: a hostorical context, Sci.-theor. and socio-political almanac, 4, 20-23 (Dnepropetrovsk, 2013)

6. Dilip Nandwani, ed. Organic farming for sustainable agriculture (Springer, 2016) 
7. V. Seufert, Z. Mehrabi, D. Gabriel, T. G. Benton, Current and Potential Contributions of Organic Agriculture to Diversification of the Food Production System Agroecosystem Diversity Reconciling Contemporary Agriculture and Environmental Quality 435-452 (2019)

8. M. Müller-Lindenlauf, Organic agriculture and carbon sequestration, Possibilities and constrains for the consideration of organic agriculture within carbon accounting systems (Natural Resources Management and Environment Department, Food and Agriculture Organization of the United Nations, Rome; Law at University of Gothenburg Vasagatan 1, PO Box 640, SE 40530 Göteborg, Sweden, 2009)

9. H. Kirchmann, G. Thorvaldsson, L. Bergström, Fundamentals of organic agriculture - past and present, In Organic crop production - ambitions and limitations 13-37 (Springer, Netherlands, 2008)

10. A. Pattanapant, G.P. Shivakoti, Opportunities and constraints of organic agriculture in Chiang Mai province, Thailand, Asia-Pacific Develop J., 16(1), 115 (2009)

11. V.I. Kiryushin, Ecological Functions of Landscapes, Eurasian Soil Sci., 51(1), 14-21 (2018)

12. Yu.A. Spiridonov, M.S. Sokolov, A.P. Glinushkin et. al., Adaptive integrated protection of plants (Pechatny gorod, Moscow, 2019)

13. V.I. Kiryushin, Theory of adaptive landscaping farming and design of agrolandscapes (KolosS, Moscow, 2011)

14. L.V. Ilyina, K.N. Drozhzhin, R.N. Ushakov, Biologization of farming - a factor of resource saving and soil fertility conservation, Crop rotation in contemporary farming 166-169 (Publishing house of MAA, Moscow, 2004)

15. N.V. Parakhin, Ecological stability and efficiency of plant breeding: theoretical bases and practical experience (Kolos, Moscow, 2002)

16. A.B. Nugmanov, Y.V. Tulayev, S.A. Tulkubayeva, S.V. Somova, Developing a system of organic farming technologies to obtain environmentally clean agricultural products (organic food) in the steppe zone of the Kostanai region, OnLine J. of Biolog. Sci., 18(2), 130-137 (2018)

17. N. Parrot, T. Marsden, The real Green Revolution: Organic and Agroecological farming in the London, Green peace Environment Trust 1-6 (2002)

18. U. Niggli, A. Slabe, O. Schmid, H. Halberg, M. Schluter, Vision for an organic food and farming research agenda to 2025 (IFOAM - EU and FiBL, 2008)

19. S. Penvern, S. Fernique, A. Cardona, Herz E. Ahrenfeldt et al., Farmers' management of functional biodiversity goes beyond pest management in organic European apple orchards, Agriculture, Ecosystems \& Environment, 284, (2019)
20. M.M. Umarov, Associative nitrogen fixation (Moscow State University, Moscow, 1986)

21. G.G. Romanov, Symbiotic plants-nitrogen fixers in the flora of the European North-East (SPbGLTU, St. Petersburg, 2014)

22. A.L. Toigildin, Comparative yielding capacity and productivity of symbiotic nitrogen fixation of leguminous crops in crop rotation of the forest steppe of the Volga region, Niva Povolzhya, 4(45), 144-151 (2017)

23. V.M. Semyonov, B.M. Kogut, Soil organic matter (GEOS, Moscow, 2015)

24. S.B. Karunaratne, T.F. Bishop, J.A. Baldock et al., Catchment scale mapping of measureable soil organic carbon fractions, Geoderma, 219, 14-23 (2014)

25. The concept of maintaining and improving soil fertility based on biologization of field feed production by natural and economic regions of Russia (Informagrotech, Moscow, 1999)

26. A.Kh. Kulikova, A.V. Karpov, I.A. Vandyshev, V.P. Tigin, Agroecological assessment of soil fertility in the Middle Volga region and the concept of its reproduction (Ulyanovsk, 2007)

27. V.A. Korchagin, O.I. Goryanin, S.V. Obushchenko, A.P. Chichkin, The concept of reproduction of fertility of black soils in the steppes of the Middle Volga region, Bull. of the Samara Sci. Center of the Russ. Acad. of Sci., 16(5-3), 1081-1085 (2014)

28. A.M. Lykov, A.M. Eskov, M.N. Novikov, Organic matter of arable soil in the Non-black soil area (Russian agricultural academy, Moscow, 2004)

29. V.G. Sychev, E.N. Efremov, The concept of the program of agrochemical measures till 2020, Innovative solutions to regulating the soil fertility of agricultural land 30 (2011)

30. N. Shikula, N. Dolja, The concept of biological function of agriculture for the production of environmentally friendly products, in Ecologicaleconomic problems of the Black Sea region 26-38 (Nikolaev, 1993)

31. N. Perez-Consuegra, L. Mirabal, L. C. Jimenez, The role of biological control in the sustainability of the Cuban agri-food system, Elementa-sci. of the Anthropoc., 6(79) (2018)

32. Yu.V. Tyutyunov, O.V. Kovalev, L.I. Titova, Spatial Demogenetic Model for Studying Phenomena Observed upon Introduction of the Ragweed Leaf Beetle in the South of Russia, Mathemat. Model. of natural phenom., 8(6), 80-95 (2013)

33. N.A. Zelensky, G.M. Zelenskaya, A.Yu. Shurkin, The yielding capacity of sun flower plants under various soil cultivation technologies, Protect. and quarant. of plants, 9, 44-47 (2014)

34. V.K. Dridiger, The problems of mastering the "zero" system of farming in the Sravropol region 
and some areas of their solution, Achievem. of sci. and engineer. in the AIC, 7, 18-19 (2012)

35. J.B. Barr, J.M. Desbiolles, J.M. Fielke, M. Ucgul, Development and field evaluation of a high-speed no-till seeding system, Soil and Tillage Research (2019)
36. A.L. Toigildin, M.I. Podsevalov, A.V. Karpov, I.A. Toigildina, T.D. Grosheva, The concept of synergism in the farming systems, Res. J. of Pharmaceut., Biolog. and Chemical Sci., 6(4), 227-229 (2015) 